\title{
МАГМАТИЧЕСКИЕ СИСТЕМЫ И УСЛОВИЯ ГЛУБИННОЙ ГИДРОТЕРМАЛЬНОЙ ЦИРКУЛЯЦИИ КЛЮЧЕВСКОЙ ГРУППЫ ВУЛКАНОВ ПО ДАННЫМ ЛОКАЛЬНОЙ СЕЙСМИЧНОСТИ И ТЕРМОГИДРОДИНАМИЧЕСКОГО МОДЕЛИРОВАНИЯ
}

\author{
(С) 2018 г. А. В. Кирюхин ${ }^{1, *}$, С. А. Федотов ${ }^{1}$, П. А. Кирюхин \\ ${ }^{1}$ Институт вулканологии и сейсмологии ДВО РАН \\ 683006 Петропавловск-Камчатский, бульвар Пийпа, 9, Россия \\ ${ }^{2} Э \Pi A M$ \\ 196084 Санкт-Петербург, ул. Заставская 22-2, Мега-Парк, Россия \\ *e-mail: AVKiryukhin2@mail.ru \\ Поступила в редакцию 26.10.2017 г.
}

\begin{abstract}
Анализ локальной сейсмичности в пределах Ключевской группы вулканов и вулкана Шивелуч в период 2000-2017 гг. позволяет выявить последовательность плоско-ориентированных кластеров землетрясений, интерпретируемых как процесс внедрения даек и силлов (магматического фракинга). Геометрия магматических тел отражает геомеханические условия в вулканических аппаратах и фундаменте вулканов. Магматический фракинг в пределах активных вулканических аппаратов приводит к формированию проницаемых резервуаров с вертикальной протяженностью до 35 км (Ключевской) и поперечником до 15 км (Шивелуч) в зависимости от геомеханического состояния вмещающих массивов горных пород. Эти резервуары являются объектами последующей гидротермальной циркуляции с возможностью формирования геотермальных, рудных и нефте-газовых месторождений. Для оценки условий формирования гидротермальных резервуаров используется TOUGH2-EOS1sc моделирование в диапазоне температур до $1200^{\circ} \mathrm{C}$ и давлений до 1000 бар.
\end{abstract}

DOI: $10.1134 / \mathrm{S} 020303061804003 \mathrm{X}$

\section{1. ВВЕДЕНИЕ}

Ключевская группа вулканов включает действующие вулканы: Ключевской, Крестовский, Ушковский, Безымянный, Плоский Толбачик. В 80 км к северо-востоку от Ключевского вулкана находится действующий вулкан Шивелуч. Гигантский стратовулкан Ключевской (возраст менее 7 тыс. лет) является наиболее продуктивным, он обеспечивает в среднем 60 млн тонн базальтов в год или 1/4 часть общего годового количества пород, извлекаемых всеми 70-ю вулканами КурилоКамчатского вулканического пояса. Ключевской вулкан с 1935 г. является предметом детальных сейсмологических и вулканологических наблюдений, результаты которых изложены в многочисленных работах и их обобщениях [Федотов, 2006; Федотов, Жаринов, 2007; Федотов и др., 2014]. В последние годы с использованием методов сейсмической томографии получены данные о динамике заполнения/дренирования магматических питающих систем Ключевского вулкана [Koulakov et al., 2013]. Сведения о гидрогеологических и геотемпературных условиях вулканогенного бассейна Ключевской группы вулканов приводятся в работах [Кирюхин и др., 2010; Кирсано- ва, Юрова, 1979], в последней работе также высказано предположение о существовании термальных вод в бассейне Толбачинского дола.

Описание гидротермальной циркуляции в магматических питающих системах вулканов также имеет важные приложения для прогноза вулканических извержений, оценки геотермальных ресурсов, условий формирования геотермальных, рудных и некоторых типов нефтегазовых месторождений, а также в связи с технологиями создания искусственных циркуляционных систем (методом гидроразрыва) для извлечения или захоронения флюидов разнообразного состава (EGS (“горячих сухих пород”), сланцевого газа, трудноизвлекаемой нефти и др.).

Одной из фундаментальных причин транспорта флюидов в верхней хрупкой оболочке земной коры является гидроразрыв и активизация критически сжатых плоско-ориентированных трещин и разломов в процессе ее эволюции [Zoback, 2010]. В работе [Shapiro, 2008] показана диффузионная природа распространения микросейсмичности при закачке воды для создания подземных циркуляционных геотермальных систем. В отличие от воды, инжекции магмы под активными 
вулканами сопровождаются формированием дайковых полей и силлов в дискретных системах трещин, ориентация которых определяется геомеханическими и геолого-структурными условиями [Кирюхин и др., 2016, 2017; Kiryukhin et al., 2017]. Теоретическое обоснование возможности использования данных локальной сейсмичности для определения эпизода инжекции магмы в трещину под активным вулканом дано в работе [Kiryukhin, 2017].

Для выявления дискретных систем плоскоориентированных кластеров землетрясений в районе Ключевской группы вулканов, интерпретируемых как зоны магматического фракинга с повышенной проницаемостью, используется программа FracDigger (№ гос. рег. 2016616880), описание применяемых алгоритмов приводится в работах [Кирюхин и др., 2016, 2017; Kiryukhin et al., 2017]. Заметим, что в отличие от алгоритма выделения плоско-ориентированных кластеров региональных землетрясений [Макеев и др., 2011], программа FracDigger использует критерий выборки по времени. В качестве исходных данных используются каталоги сейсмических данных КФ ФИЦ ЕГС РАН по локальным сетям сейсмических станций в пределах активных вулканов Камчатки за период 2000-2017 гг. Для термогидродинамического моделирования гидротермальной циркуляции в вулканических системах используется программа iTOUGH2EOS1sc [Magnúsdóttir, Finsterle, 2015], позволяющая воспроизводить на модели условия двухфазной неизотермической фильтрации в трещиннопористой среде в диапазоне температур от 2 до $1200^{\circ} \mathrm{C}$ и давлений от 0.2 до 1000 бар.

\section{2. ИНЖЕКЦИИ МАГМЫ В РАЙОНЕ КЛЮЧЕВСКОЙ ГРУППЫ ВУЛКАНОВ в 2000-2017 ГГ. ПО ДАННЫМ ЛОКАЛЬНОЙ СЕЙСМИЧНОСТИ}

Для реконструкции последовательности инжекций магмы в районе Ключевской группы вулканов использован каталог данных сейсмического мониторинга по 19-ти сейсмическим станциям КФ ФИЦ ЕГС РАН за период 2000-2017 гг. (общее число землетрясений, зарегистрированных с 01.01.2000 г. по 23.08.2017 г., составляет 122451). Методика расчета плоско-ориентированных кластеров землетрясений и аппроксимирующих плоскостей с использованием программы FracDigger изложена в работах [Кирюхин и др., 2016, 2017; Kiryukhin et al., 2017], соответствующие расчетные площадки интерпретируются как зоны внедрения магмы в форме даек и силлов. При расчетах принимались следующие параметры выделения плоско-ориентированных кластеров: близость по времени - 30 сут, близость по расстоянию в горизонтальной плоскости -6 км, стан- дартное отклонение от плоскости 1000 м. В результате расчетов выявлено 1788 кластеров, включающих 117412 землетрясения (96\% от всего количества зарегистрированных землетрясений) (рис. 1-6).

Вертикальный разрез вдоль оси Ключевской группы вулканов (см. рис. 2) от Толбачикских вулканов до вулкана Шивелуч показывает, что при экстраполяции даек вулканов Толбачик и Шивелуч на глубину они пересекаются в точке с абс. отметкой от -165 до -205 км под Ключевским вулканом, где и предполагается область первичного выплавления магм или первичный магматический очаг, обеспечивающий магматическое питание всех активных вулканов Ключевской группы (Ключевской, Плоский Толбачик, Безымянный, Шивелуч).

Непосредственно под Ключевским вулканом инжекции магмы в 2000-2017 гг. концентрировались в интервалах глубин от -31 до -28 км абс. $(35 \%)$ и от -1 до +2 км абс. (20\%), где можно предполагать коровый (К2) и периферический (K1) магматические очаги, соответственно (см. рис. 2 и 3). В коровом очаге (К2) выделяются дайки с углами падения $70-80^{\circ}(30 \%)$ и силлы с углами падения $15-20^{\circ}(8 \%)$, также отмечается увеличение числа даек субширотного простирания, по которым осуществляется магматическое питание расположенных вблизи вулканов Безымянный и Крестовский. За рассматриваемый период времени (2000-2017 гг.) в очаге К2 зафиксировано девять эпизодов интенсивного внедрения даек и семь эпизодов интенсивного внедрения силлов, при этом эпизоды инжекции даек предваряют с упреждением в 1 г. инжекции силлов (два случая) или синхронизированы (пять случаев) или не завершаются внедрением силлов (один случай), что свидетельствует об изменении геомеханического состояния в окрестности очага К2 в диапазоне от условий горизонтального растяжения до радиального сжатия. В периферическом очаге (K1) углы и азимуты падения даек и силлов распределены достаточно равномерно, при этом отмечается некоторое увеличение числа наклонных даек с углами падения $35^{\circ}-50^{\circ}$ и $65^{\circ}-80^{\circ}$, также отмечается группа даек с азимутами падения в северо-восточном направлении (т.е. с простиранием по линии вулкан Ключевской - вулкан Крестовский).

Вулкан Толбачик характеризуется инжекциями магмы в интервале глубин от -8 до -1 км абс., большая часть даек имеет углы падения свыше $60^{\circ}$ (67\%) (см. рис. 4), выделяется группа даек с азимутами падения $180^{\circ}-220^{\circ}$ (26\%) (с простиранием по линии вулкан Острый Толбачик - Плоский Толбачик - Большая Удина).

Вулкан Шивелуч характеризуются инжекциями магмы в интервалах глубин от -4 до -2 км абс. 


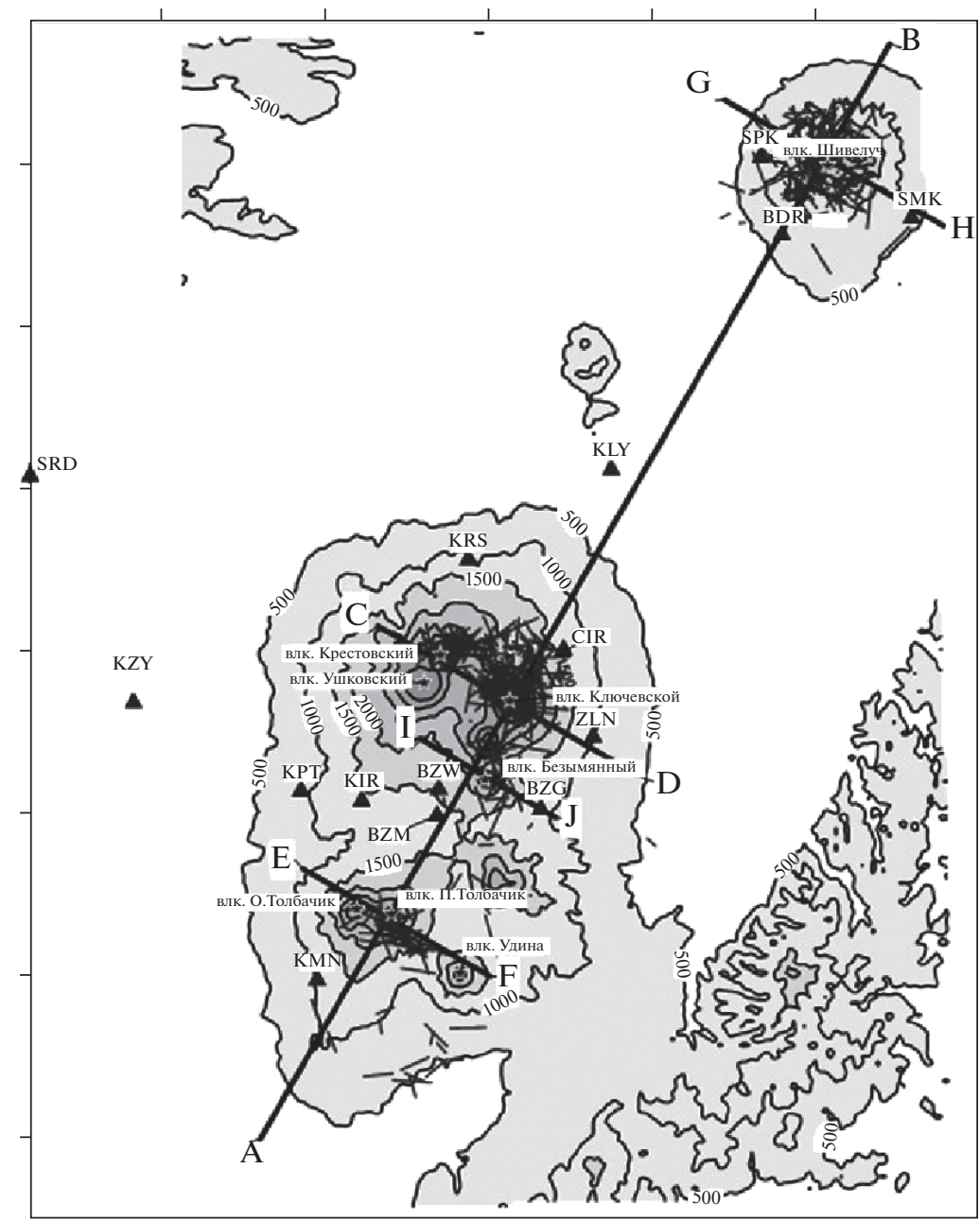

Рис. 1. Схема Ключевской группы вулканов с изображением топографической поверхности, позиций сейсмических станций (треугольники) и положения вертикальных разрезов AB, CD, EF, GH, IJ (см. рис. 2-6). На рисунке также показаны дайки (следы площадок плоско-ориентированных кластеров землетрясений) на отм. -3000 м абс. Разметка осей 20 км.

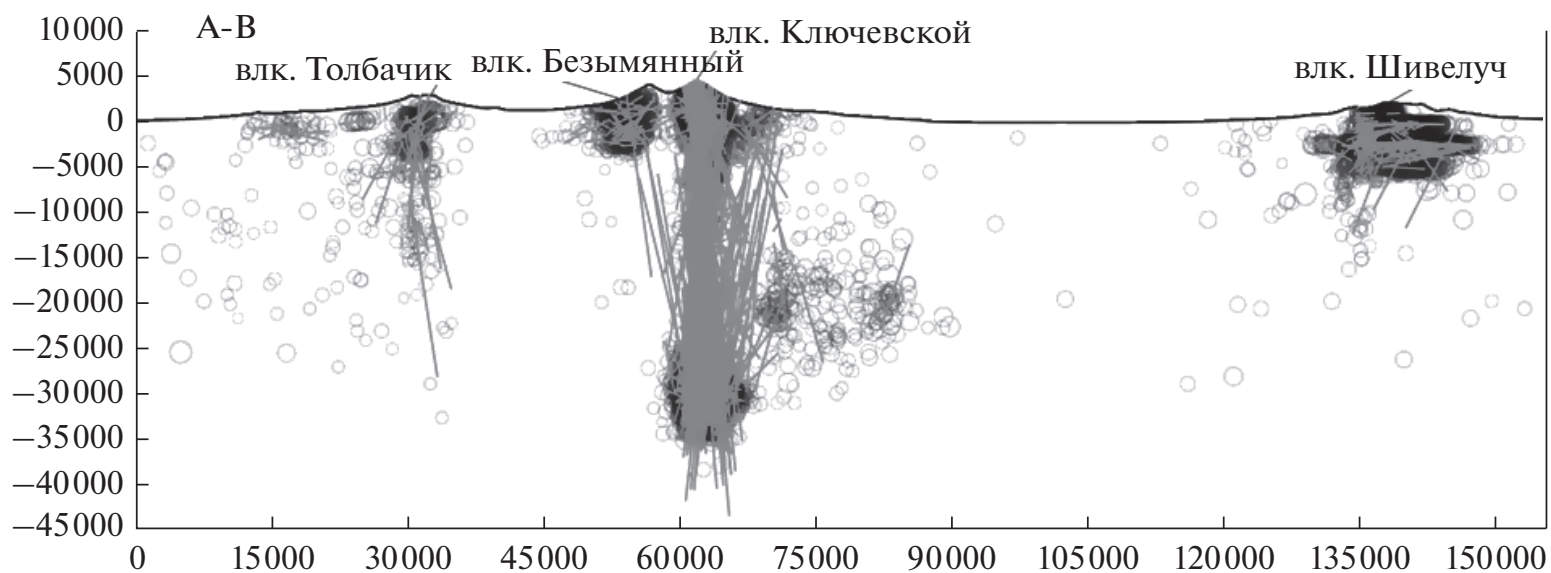

Рис. 2. Распределение даек (следы площадок плоско-ориентированных кластеров землетрясений) и гипоцентры землетрясений (2000-2017, данные КФ ФИЦ ЕГС РАН) в вертикальном разрезе АВ (положение разреза показано на рис. 1). 


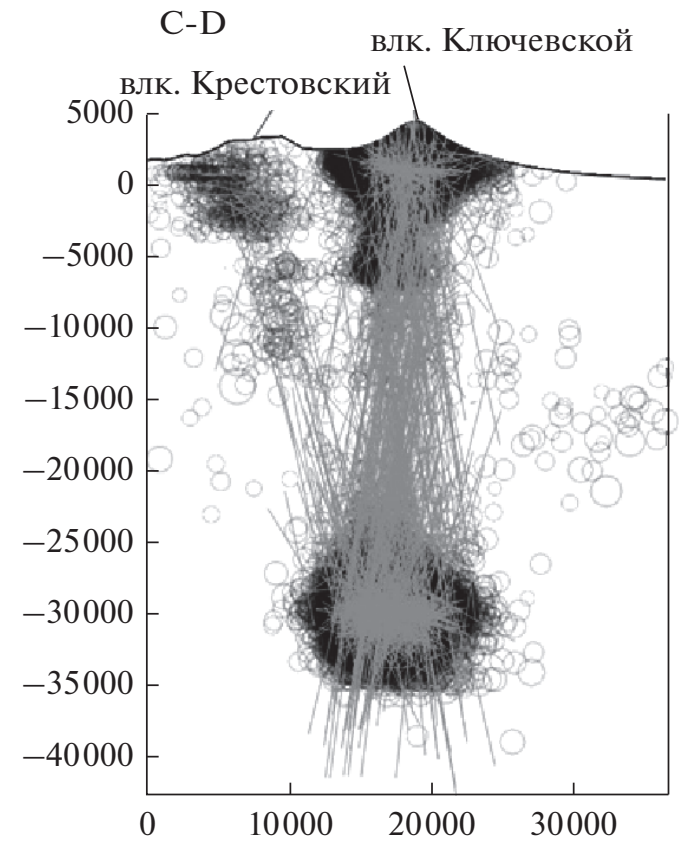

Рис. 3. Распределение даек (следы площадок плоскоориентированных кластеров землетрясений) и гипоцентры землетрясений (2000-2017, данные КФ ФИЦ ЕГС РАН) в вертикальном разрезе CD (положение разреза показано на рис. 1).

$(37 \%)$ и от 0 до +2 км (47\%), где можно предполагать наличие двух периферических магматических очагов (см. рис. 5). Инжекции магмы преимущественно происходят в виде силлов с углами падения до $5^{\circ}$, с некоторым трендом преобладания азимута падения на запад.

Вулкан Безымянный получает магматическое питание из корового магматического очага Ключевского вулкана (K2), находящегося, как упоминалось выше, на глубине от -31 до -28 км абс. (см. рис. 2 и 6). Под Безымянным инжекции магмы происходят в диапазоне глубин от -2 до +2 км (93\%), где можно предполагать периферический магматический очаг (см. рис. 6). Инжекции магмы происходят, преимушественно, в виде силлов с углами падения до $15^{\circ}(27 \%)$ и пологих даек с углами падения до $50^{\circ}(58 \%)$, азимуты падения распределены равномерно по всем направлениям.

Оценка объемов инжекции магмы из магматических очагов вулканов может быть выполнена с использованием эмпирических зависимостей максимальной магнитуды триггерной сейсмичности от объема инжектируемой магмы (Fujii et al., 2018, личное сообщение):

$$
M=0.67 \lg (V)-0.82,
$$

где $M$ - максимальная магнитуда триггерных сейсмических событий, $V$ - объем инжекций. Результаты оценки объемов инжекции даек и силлов за период 2000-2017 гг. для рассматриваемых вулка-

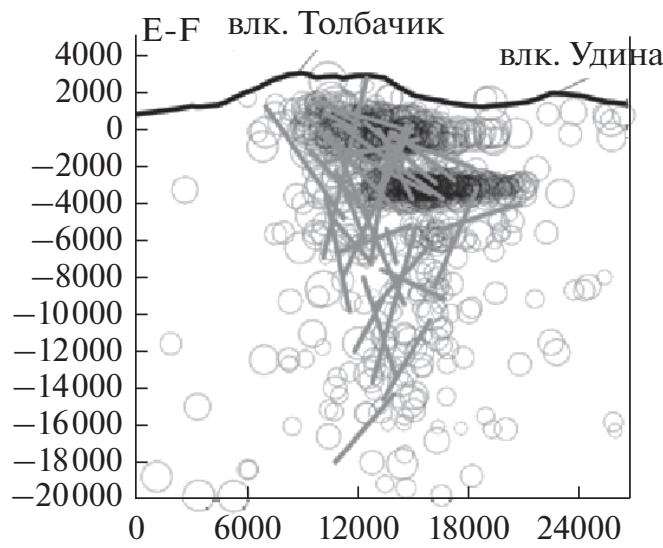

Рис. 4. Распределение даек (следы площадок плоскоориентированных кластеров землетрясений) и гипоцентры землетрясений (2000-2017, данные КФ ФИЦ ЕГС РАН) в вертикальном разрезе ЕF (положение разреза показано на рис. 1).

нов Ключевской группы по формуле (1) приводятся в табл. 1. Принимая энтальпию магмы с температурой $1200^{\circ} \mathrm{C}$ равной $H_{m} \approx 1000 \mathrm{\kappa Дж/кг,} \mathrm{плот-}$ ность магмы $\rho=2800 \mathrm{Kг} / \mathrm{M}^{3}$, можно оценить массовый расход $Q$ и мощность тепловых источников $q$ за счет инжекций магмы:

$$
\begin{aligned}
& Q=\frac{V \rho}{\Delta t}, \\
& q=Q H_{m},
\end{aligned}
$$

где $\Delta t-$ время с 01.01 .2000 г. по 23.08.2017 г. в с. Рассчитанные по формуле (2) данные по тепловой мощности инжекций магмы в рассматриваемых вулканических аппаратах приводятся в табл. 1.

Сравнивая оценки массовых расходов инжекции магмы под вулканами, приведенные в табл. 1, с оценками продуктивности соответствующих вулканов из работы [Поляк, Мелекесцев, 1981], приходим к следующим соотношениям между расходами магмы аккумулирующейся под вулканами и извергающейся из них на поверхности Земли: вулкан Ключевской $-0.8 \%$, вулкан Безымянный $-14.9 \%$, вулкан Толбачик $-23.2 \%$, вулкан Шивелуч - $72.9 \%$.

\section{3. ГЕОМЕХАНИЧЕСКИЕ УСЛОВИЯ ПОД ВУЛКАНАМИ КЛЮЧЕВСКОЙ, БЕЗЫМЯННЫЙ, ТОЛБАЧИК И ШИВЕЛУЧ}

Ориентация даек и силлов, образующихся при инжекции магмы под вулканами, является индикатором геомеханических условий в их пределах. В данной работе мы будем придерживаться по возможности классификации геомеханического состояния по Андерсону [Zoback, 2010] по соотношению вертикального стресса $S_{v}$, максимального горизонтального стресса $S_{H \max }$ и минималь- 


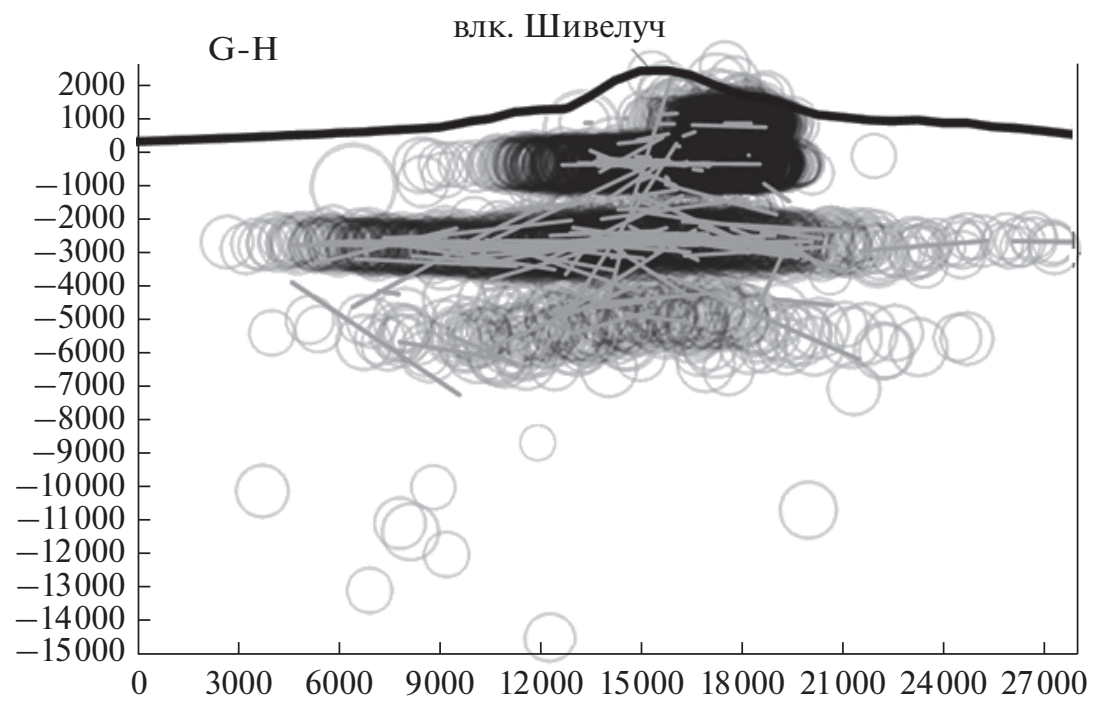

Рис. 5. Распределение даек (следы площадок плоско-ориентированных кластеров землетрясений) и гипоцентры землетрясений (2000-2017, данные КФ ФИЦ ЕГС РАН) в вертикальном разрезе GН (положение разреза показано на рис. 1).

ного горизонтального стресса $\mathrm{S}_{\mathrm{hmin}}$ (или, с учетом флюидного (порового) давления, соответствующих эффективных напряжений $\left.\sigma_{\mathrm{v}}, \sigma_{\mathrm{Hmax}}, \sigma_{\mathrm{hmin}}\right)$. В частности условия NF (normal faults, образования нормальных разломов или сбросов) определяются при $\mathrm{S}_{\mathrm{v}}>\mathrm{S}_{\mathrm{Hmax}}>\mathrm{S}_{\mathrm{hmin}}$; условия SS (strike-slip, латеральных сдвигов) соответствуют $\mathrm{S}_{\mathrm{Hmax}}>\mathrm{S}_{\mathrm{v}}>$ $>\mathrm{S}_{\mathrm{hmin}}$; условия RF (reverse-fault, взбросов) во3никают при $S_{\text {Hmax }}>S_{\text {hmin }}>S_{v}$. Также принимается, что условием гидроразрыва является превышение флюидного давления над минимальным стрессом и плоскость трещины гидроразрыва перпендикулярна его направлению, а земная кора находится в состоянии фрикционного равновесия (т.е. минимальное и максимальное эффективные напряжения связаны условием разрушения Мора). Для расчетов стрессов далее мы будем использовать данные из работы [Федотов и др., 2014].

Исходя из ориентации даек и силлов в коровом магматическом очаге Ключевского вулкана (K2), которые внедряются синхронно, можно предположить геомеханические условия радиального растяжения $\operatorname{NF}\left(\sigma_{\mathrm{v}}>\sigma_{\mathrm{Hmax}}=\sigma_{\mathrm{hmin}}\right)$, с образованием крутопадающих даек разнообразного простирания отходящих от подошвы и кровли частично расплавленного магматического очага, находящегося в условиях радиального бокового сжатия RF $\left(\sigma_{\mathrm{v}}<\right.$ $\left.<\sigma_{\mathrm{Hmax}}=\sigma_{\mathrm{hmin}}\right)$ на глубине от -31 до -28 км абс. (см. рис. 3).

Периферический магматический очаг Ключевского вулкана (K1) находится в целом в геомеханическом состоянии с максимальным радиальным стрессом, поэтому инжекции даек происходят с разнообразными углами и азимутами падения (см. рис. 3). Геомеханическая схема Андерсона не применима в данном случае.

Толбачикские вулканы находятся в геомеханических условиях NF с осью зоны растяжения по линии Острый Толбачик-Плоский ТолбачикБольшая Удина (азимут запад-север-запад 290) (см. рис. 1). Но при извержении 2012 г. геомеханические условия изменились, в результате повышения давления магмы на условия RF бокового сжатия с образованием силлов на глубине около 0 км абс. и магмовыводящей дайки северосеверо-восточного простирания [Кирюхин и др., 2016].

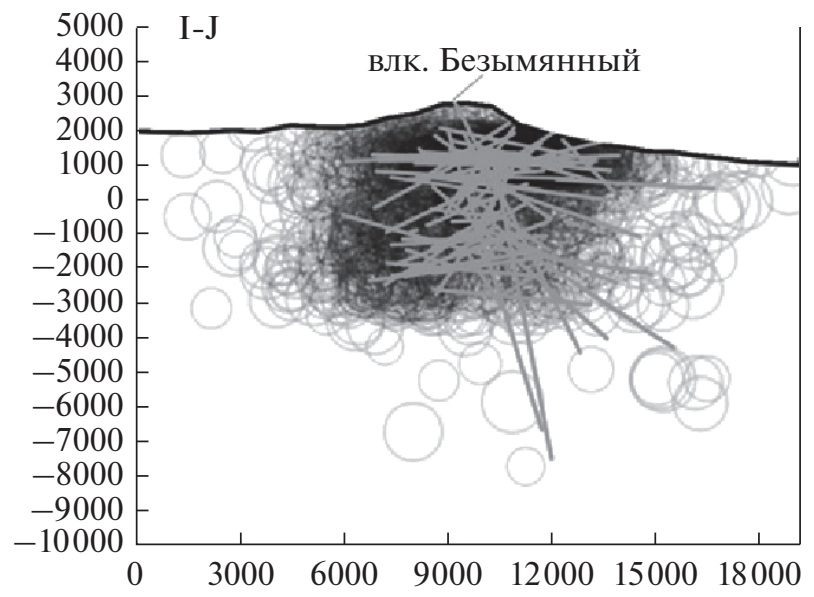

Рис. 6. Распределение даек (следы площадок плоскоориентированных кластеров землетрясений) и гипоцентры землетрясений (2000-2017, данные КФ ФИЦ ЕГС РАН) в вертикальном разрезе IJ (положение разреза показано на рис. 1). 
Таблица 1. Расчетные объемы инжекции магмы в магматических очагах вулканов и соответствующая тепловая мощность за 2000-2017 гг.

\begin{tabular}{l|c|c|c|c}
\hline \multicolumn{1}{c|}{ Вулкан } & $\begin{array}{c}\text { Диапазон глубин, } \\
\text { км абс. }\end{array}$ & Макс. магнитуда & Объем, млн м ${ }^{3}$ & $\begin{array}{c}\text { Тепловая мощность, } \\
\text { МВт (расход магмы кг/с) }\end{array}$ \\
\hline $\begin{array}{l}\text { Ключевской (пери- } \\
\text { ферический очаг К1) }\end{array}$ & $-31 \ldots-28$ & 3.05 & 0.6 & 3.0 \\
Ключевской (коро- & $-1 \ldots+2$ & 3.45 & 2.4 & 11.9 \\
вый очаг К2) & $-2 \ldots+2$ & 3.65 & 4.7 & 23.6 \\
Безымянный & $-8 \ldots-1$ & 3.95 & 13.2 & 66.2 \\
Толбачик & $-4 \ldots-2,0 \ldots+2$ & 4.1 & 22.0 & 110.9 \\
Шивелуч & & & \\
\hline
\end{tabular}

Вулкан Шивелуч характеризуется условиями радиального бокового сжатия RF с минимальным вертикальным эффективным стрессом $\left(\sigma_{\mathrm{v}}<\sigma_{\mathrm{Hmax}}=\right.$ $\left.=\sigma_{\mathrm{hmin}}\right)$, что благоприятно для образования силлов в диапазоне глубин от -4 до -2 км абс. и от 0 до +2 км абс. Нижняя зона образования силлов имеет поперечник около 17 км, верхняя - около 5 км (см. рис. 5).

Вулкан Безымянный также характеризуется условиями радиального бокового сжатия RF c минимальным вертикальным эффективным стрессом $\left(\sigma_{\mathrm{v}}<\sigma_{\mathrm{Hmax}}=\sigma_{\mathrm{hmin}}\right)$, что благоприятно для образования силлов в диапазоне глубин от -2 до +2 км абс., зона формирования силлов имеет поперечник около 8 км (см. рис. 6). Питание магмой осуществляется из корового очага Ключевского вулкана (K2).

\section{TOUGH2-МОДЕЛИРОВАНИЕ ГЛУБИННОЙ ГИДРОТЕРМАЛЬНОЙ ЦИРКУЛЯЦИИ \\ 4.1. Концептуальная модель глубинной гидротермальной циркуляции}

Рассмотрим термогидродинамические условия глубинной гидротермальной циркуляции в трещиноватых резервуарах, сформированных в результате магматического фракинга в фундаменте активного вулканического аппарата на примере вулканов Ключевской группы. Такая циркуляция, очевидно, возможна до глубин хрупкого разрушения горных пород, оцениваемых по сейсмическим данным для Ключевского вулкана величиной около -35 км абс., для Толбачинских вулканов - 13 км абс., для вулкана Шивелуч около -6 км абс. (см. рис. 2, 3, 4, 5). Геотермический градиент составляет в районе Ключевской группы вулканов $24^{\circ} \mathrm{C} / \mathrm{kм}$, что при формальном расчете показывает возможность достижения температуры 850,322 и $164^{\circ} \mathrm{C}$ на соответствующих глубинах. Нисходящая инфильтрация холодных вод из построек вулканов должна сопровождаться возникновением естественных циркуляционных систем и перераспределением температур с возможным формированием продуктивных гидротермальных резервуаров. Как показывает опыт разбуривания высокотемпературных гидротермальных резервуаров мира, предельной температурой для гидротермальной водонапорной циркуляции является величина $340-350^{\circ} \mathrm{C}$ [Кирюхин и др., 1991]. Таким образом, возможна оценка минимального расхода водного питания, обеспечивающих глубинную гидротермальную циркуляцию в системах магматического фракинга Ключевской группы вулканов в диапазоне предельных температур $340-350^{\circ} \mathrm{C}$ и времени 5-7 тыс. лет. Для получения указанных оценок воспользуемся методом термогидродинамического TOUGH2-моделирования [Pruess et al., 1999] на примере системы peзервуаров магматического фракинга Ключевского вулкана.

\section{2. Описание TOUGH2-модели и результаты моделирования}

Для осуществления 2D термогидродинамического моделирования в плоскости разреза (рис. 7) собрана модель со следующими характеристиками.

1. Геометрия модели - от топографической поверхности до глубины -35 км абс.;

2. Вычислительная сетка - прямоугольная с шагом 1 км по направлению X и по направлению Z;

3. Материальные свойства - проницаемый домен зоны магматического фракинга (проницаемость 1 e-13 м²) и непроницаемый домен вмещающих пород (проницаемость 1е-16 м²), в табл. 2 приводится сводка петрофизических и фильтрационноемкостных свойств, определенных на модели;

4. Граничные атмосферные условия - постоянное давление 1 бар и температура $10^{\circ} \mathrm{C}$ на топографической поверхности (домен BON1), зоны разгрузки на левой и правой границах модели (1 бар на отметке 0 м абс., домен BON2), соответствующие дренированию вулканогенного бас- 


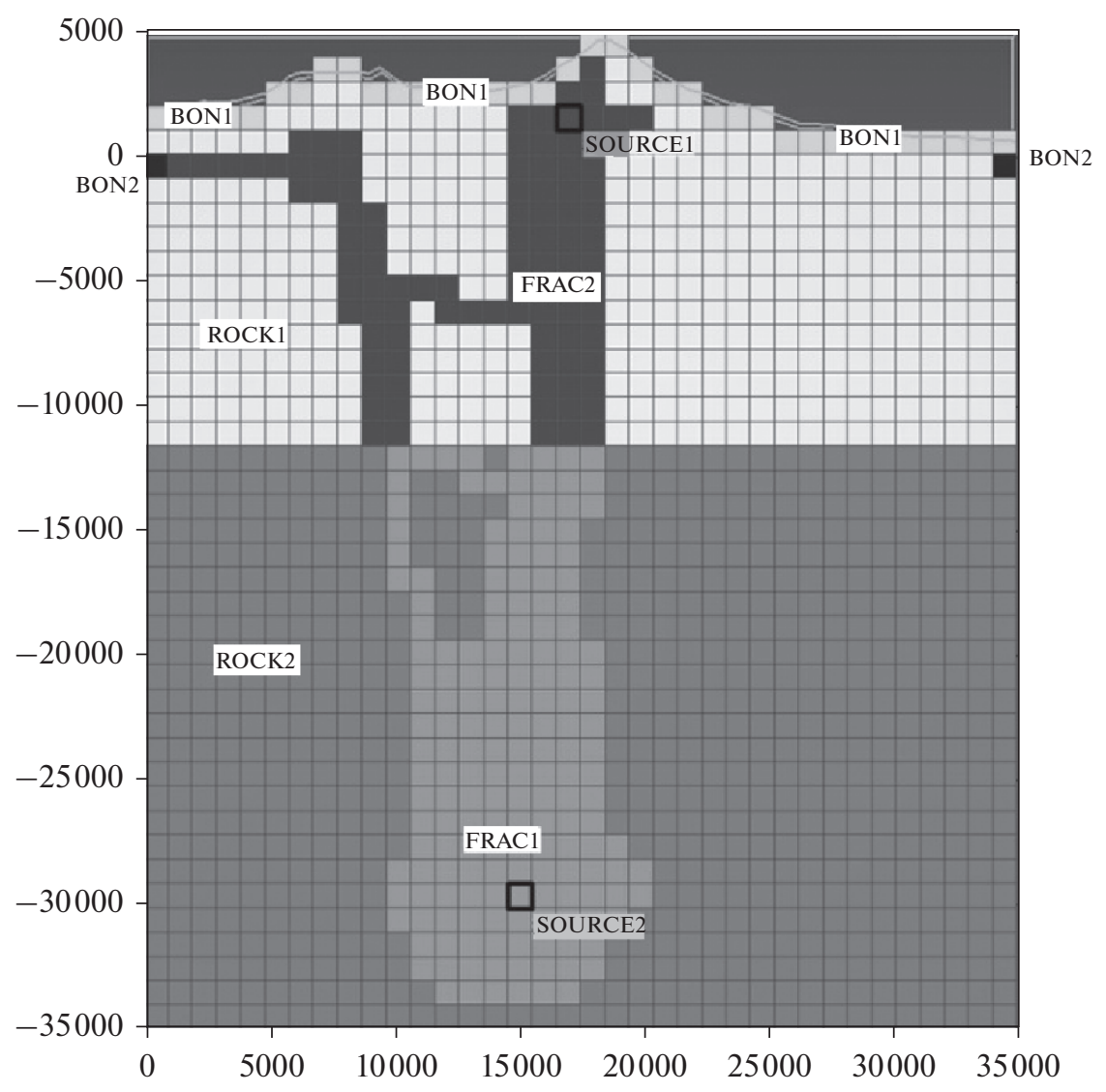

Рис. 7. Геометрия TOUGH2 модели для анализа гидротермальной циркуляции под Ключевским вулканом.

сейна Ключевской группы вулканов р. Камчатка и р. Хапица;

5. Начальные условия - гидростатическое распределение порового давления и линейное возрастание температуры с глубиной $\left(24^{\circ} \mathrm{C} / \mathrm{KM}\right)$ до глубины 10 км, ниже начальная температура задана $340^{\circ} \mathrm{C}$;

6. Тепловые источники 12 МВт (SOURCE2) и 3 MBт (SOURCE1), соответствующие тепловыде- лению при инжекции даек в коровый и периферический очаги соответственно, см. табл. 1;

7. Кондуктивный тепловой поток в основании модели $60 \mathrm{e}-3 \mathrm{BT} / \mathrm{M}^{2}$;

8. Время моделирования - 10 тыс. лет.

В первом варианте моделирования нижняя граница модели была ограничена глубиной -11.5 км абс., поскольку диапазон области определения модуля состояния флюида EOS1sc по давлению до

Таблица 2. Фильтрационно-емкостные и петрофизические параметры пород, определенные на модели

\begin{tabular}{|c|c|c|c|c|c|c|}
\hline \multirow[b]{2}{*}{ Параметры } & \multicolumn{6}{|c|}{ Домены модели } \\
\hline & ROCK1 & ROCK2 & FRAC1 & FRAC2 & $\begin{array}{c}\text { BON1 } \\
\text { (Fixed State) }\end{array}$ & $\begin{array}{c}\text { BON2 } \\
\text { (Fixed State) }\end{array}$ \\
\hline Проницаемость, $10^{-15} \mathrm{M}^{2}$ & 0.1 & 0.1 & 100 & 100 & 0.1 & 0.1 \\
\hline Пористость & 0.001 & 0.001 & 0.01 & 0.01 & & \\
\hline Минеральная плотность, кг/м & 2600 & 2600 & 2600 & 2600 & & \\
\hline Теплопроводность, Вт $/ \mathrm{M}^{\circ} \mathrm{C}$ & 2.0 & 2.0 & 2.0 & 2.0 & 2.0 & 2.0 \\
\hline
\end{tabular}

Примечание. Относительные проницаемости заданы функциями Кори с $\mathrm{S}_{\mathrm{lr}}=0.3, \mathrm{~S}_{\mathrm{gr}}=0.05$, удельная теплоемкость 1000 Дж/кг ${ }^{\circ} \mathrm{C}$ заданы во всех доменах модели. Плотность, пористость и теплопроводность заданы по данным (Черняк и др., 1987), проницаемость задана по аналогии с изученными геотермальными месторождениями [Кирюхин, 2002; Kiryukhin et al., 2008; Kiryukhin et al., 2017]. 


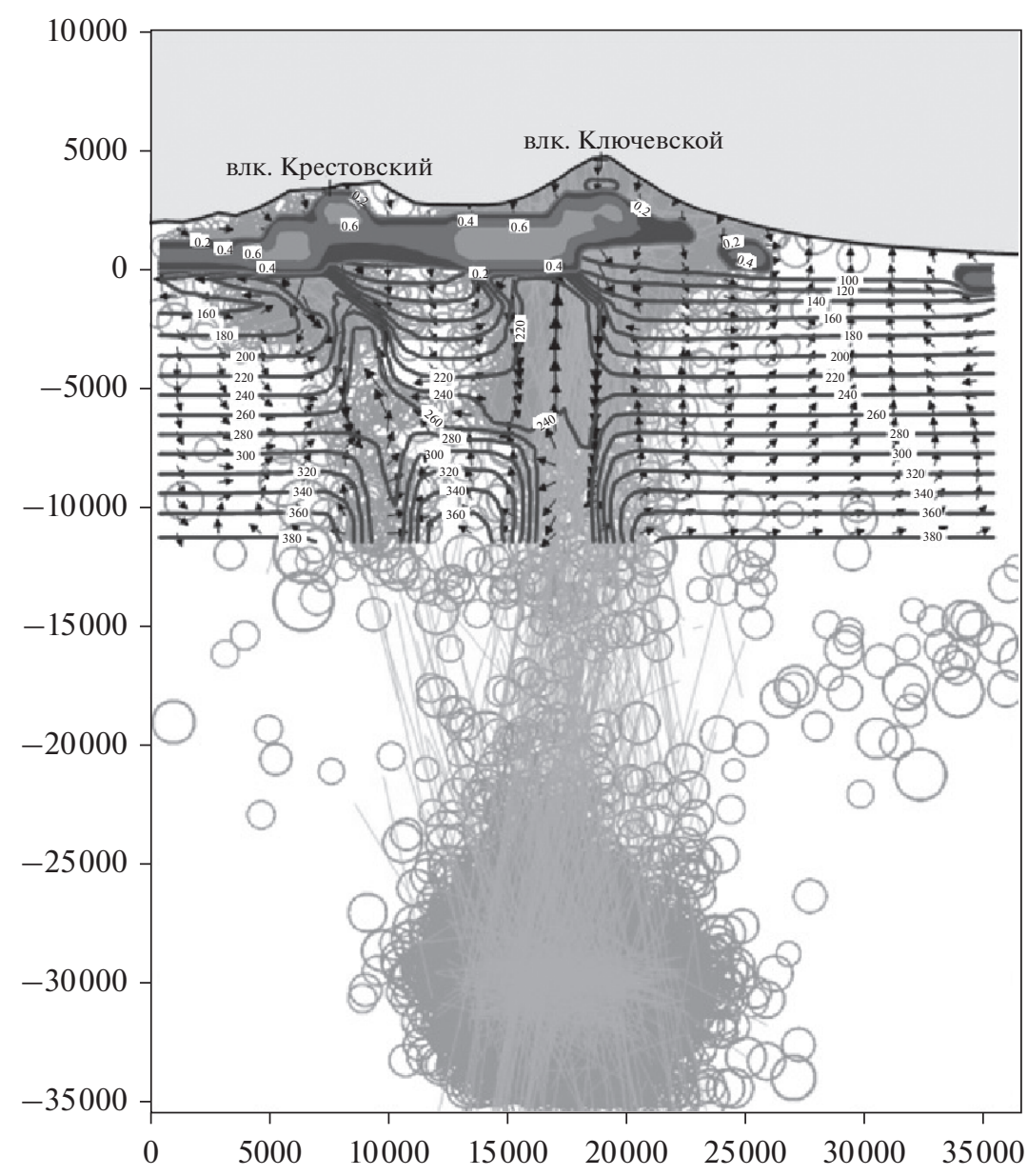

Рис. 8. Результаты iTOUGH2-EOS1sc моделирования распределения температуры, насыщения газовой фазы и массовых потоков флюида в вертикальном разрезе, проходящем через вулканы Ключевской и Крестовский (см. рис. 3). Распределение температуры показано жирными изолиниями, распределение насыщения газовой фазы серыми изолиниями с закраской, векторы массовых потоков флюида показаны стрелками, в качестве подложки использован рис. 3. Масштаб по осям координат задан в метрах. На рис. показан вариант моделирования $12 B$.

1000 бар, что соответствует указанной выше глубине при гидростатическом распределении давления. Результаты моделирования в виде распределения температуры, насыщения газовой фазы и поля скоростей фильтрации показаны на рис. 8. На модели фиксируется образование двух неглубокозалегающих высокотемпературных гидротермальных резервуаров с температурой от 220 до $240^{\circ} \mathrm{C}$ (расход циркуляции $13.6 \mathrm{\kappa r} / \mathrm{c}$ ) в зоне магматического фракинга под вулканом Ключевской и с температурой от 260 до $280^{\circ} \mathrm{C}$ (расход циркуляции $12.5 \mathrm{kг} / \mathrm{c}$ ) в зоне магматического фракинга под вулканом Крестовский. Их формирование связано с субвертикальной циркуляцией воды от областей водного питания (определяемых приподнятыми участками вулканов) к зонам разгрузки на боковых границах модели через транзитную зону тепловой конвекции в проницаемых зонах магматического фракинга глубокого заложения под активными вулканами, указанными выше.
Тепловое питание гидротермальных резервуаров осуществляется за счет перераспределения температур в зонах магматического фракинга и съема тепловой энергии вмещающих горных пород, прогретых до $340^{\circ} \mathrm{C}$. Представленный механизм отличается от классических представлений о формировании высокотемпературных гидротермальных резервуаров [Кирюхин и др., 1991], предполагающих наличие магматических очагов как необходимых источников теплового питания высокотемпературных гидротермальных систем.

Во втором варианте моделирования (рис. 9) нижняя граница модели была опущена до реальной глубины подошвы зоны магматического фракинга под Ключевским вулканом, т.е. до глубины -35000 м. Заметим, что возможность циркуляции подземных вод до такой глубины доказывается наличием там плоско-ориентированных клатеров землетрясений, указывающих на наличие хрупкого режима деформаций с образованием трещин 


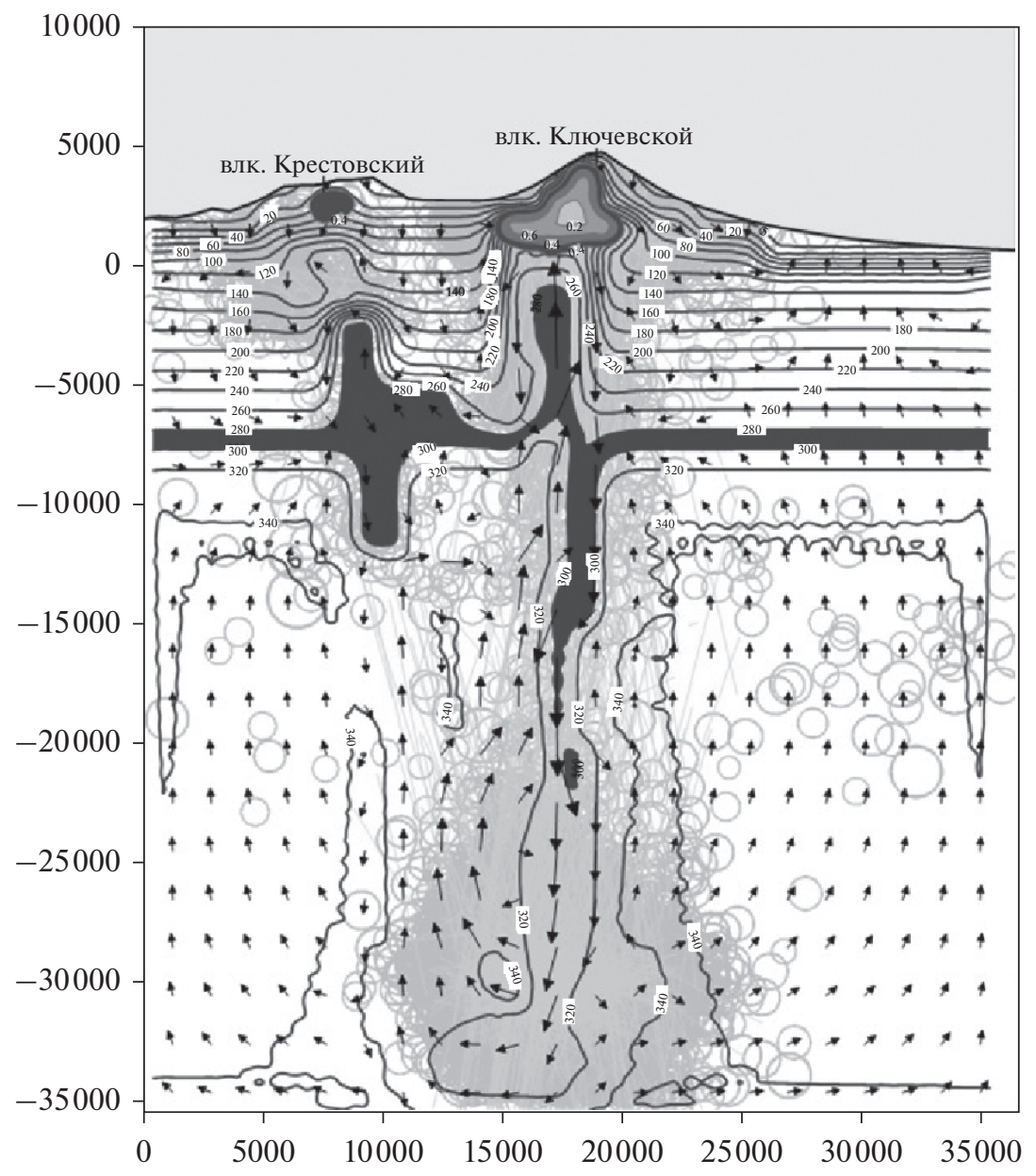

Рис. 9. Результаты iTOUGH2-EOS1sc моделирования распределения температуры, насыщения газовой фазы и массовых потоков флюида в вертикальном разрезе, проходящем через вулканы Ключевской и Крестовский (см. рис. 3). Распределение температуры показано жирными изолиниями, распределение насыщения газовой фазы серыми изолиниями с закраской, векторы массовых потоков флюида показаны стрелками, в качестве подложки использован рис. 3. Масштаб по осям координат задан в метрах. На рис. показан вариант моделирования 12С.

гидроразрыва. Для осуществления моделирования до таких глубин величина $g$ (ускорение свободного падения) была задана на модели равной $3 \mathrm{~m} / \mathrm{c}^{2}$. Это позволило на модели снизить величину гидростатического градиента и остаться в рамках области определения модуля состояния флюида EOS1sc (1000 бар).

В связи с этим заметим, что анализ управляющих уравнений свободной конвекции в вертикальной проницаемой зоне при линейной зависимости плотности воды от температуры и однофазной фильтрации показывает [Кирюхин, Сугробов, 1987 , с. 84 , уравнения 3.17-3.20], что расход гидротермальной циркуляции пропорционален $K=\frac{k \rho g}{\mu}$, где $k-$ проницаемость $\left(\mathrm{м}^{2}\right), \rho-$ плотность воды (кг $\left./ \mathrm{M}^{3}\right), \mu$ - вязкость (Па с), $g$ - ускорение свободного падения $\left(\mathrm{m} / \mathrm{c}^{2}\right)$. Т.е. изменение $g$ эквивалентно пропорциональному изменению проницаемости (уменьшению в 3.27 раза) в указанном выше случае.

В двухфазных системах уменьшение g приведет при прочих одинаковых условиях к увеличению глубины вскипания, этот эффект - нелинейный и не может быть скомпенсирован а рамках рассматриваемой модели. В дальнейшем планируется модификация модуля EOS1sc для использования его в условиях до глубин 35 км при экстраполяции свойств из региона 1 (см. рис. 1), [Magnúsdóttir, Finsterle, 2015].

Результаты моделирования в виде распределения температуры, насыщения газовой фазы и поля скоростей фильтрации показаны на рис. 9. На модели фиксируется образование двух неглубокозалегающих высокотемпературных гидротермальных резервуаров с температурой от 280 до $300^{\circ} \mathrm{C}$ (расход циркуляции 106.0 кг/с или 140 МВт) в зоне магматического фракинга под 
вулканом Ключевской и с температурой от 280 до $300^{\circ} \mathrm{C}$ (расход циркуляции 12.7 кг/с или $18 \mathrm{MBT}$ ) в зоне магматического фракинга под вулканом Крестовский. Их формирование связано с субвертикальной циркуляцией воды от областей водного питания (определяемых приподнятыми участками вулканов) к зонам разгрузки на боковых границах модели через транзитную зону тепловой конвекции в проницаемых зонах магматического фракинга глубокого заложения под активными вулканами, указанными выше. Тепловое питание гидротермальных резервуаров осуществляется за счет перераспределения температур в зонах магматического фракинга и съема тепловой энергии вмещающих горных пород, прогретых до $340^{\circ} \mathrm{C}$.

\section{5. ОБСУЖДЕНИЕ ПОЛУЧЕННЫХ РЕЗУЛЬТАТОВ}

Существуют две точки зрения на формирование и функционирование магматичеких очагов в районе Ключевской группы вулканов. Первая из них изложена в работах С.А. Федотова [2006], С.А. Федотова и др. [2011] и основана на модели проточного очага с размерами, изменяющимися в зависимости от температуры входящей и выходящей магмы, времени существования и интенсивности теплообмена с вмещающими горными породами. Такого типа модели предполагают устойчивое существование под активными вулканами однородных насыщенных жидкой магмой очагов эллипсоидальной формы. Эти представления основаны на геологических, сейсмологических, геодезических данных и моделировании эволюции выплавления магматической камеры под вулканами. $\mathrm{B}$ соответствии с этими представлениями под вулканом Плоский Толбачик располагается периферический магматический очаг с поперечными размерами до 6 км, кровля очага находится на глубине 2 км ниже уровня моря, вертикальная мощность 3.2-3.9 км, объем 40-70 км³. Эти представления отражены также в геофизической модели магматической питающей системы Ключевской группы вулканов [Федотов и др., 2010], где предполагается наличие устойчивых коровых магматических очагов под Ключевским вулканом на глубинах от -32 до -26 км абс. и на глубинах от -4 до 0 км абс. $\left(100\right.$ км$\left.^{3}\right)$, под вулканом Безымянный на глубинах от -20 до -7 км абс. $\left(100 \mathrm{Kм}^{3}\right)$. Накопление магм может происходить также в мощных роях питающих силлов и даек.

Другая модель основана на сейсмической томографии с выявлением динамики изменения 3D распределения отношения скоростей продольных и поперечных волн $V_{\mathrm{p}} / V_{\mathrm{s}}$, повышение которого характеризует увеличение степени насыщения жидкой фазы (магмы) под вулканами [Koulakov et al., 2013]. Активная динамика изменения
$V_{\mathrm{p}} / V_{\mathrm{s}}$ показывает два уровня накопления флюида под Ключевским вулканом: на глубине 10-12 км и вблизи поверхности. То, что указанный флюид является магмой, аргументируется тем, что во время извержений вулканов Ключевской и Безымянный в 2005 г. наблюдалось увеличение $V_{\mathrm{p}} / V_{\mathrm{s}}$. Магматические резервуары под Ключевской группой вулканов рассматриваются как зоны неполного магмонасыщения с быстро изменяющимся (годы) насыщением расплава и его быстрым пульсирующим перемещением в геологическом пространстве. Существование стационарной аномалии $V_{\mathrm{p}} / V_{\mathrm{s}}$ на глубине 12 км под Ключевским вулканом интерпретируется как наличие флюидопроводника от первичного магматического очага Ключевского вулкана. Результаты сейсмотомографии очень сильно зависят от сильно меняющихся количества и координат имеющихся гипоцентров и часто расходятся в различных исследованиях.

Дополнительные результаты получены при изучении свойств кластеров локальных землетрясений Ключевской группы вулканов и вулкана Шивелуч в 2000-2017 гг. 3D картирование плоско-ориентированных кластеров землетрясений, связанных с инжекциями магмы под Ключевской группой в 2000-2017 гг., уточняет позиции коровых магматических очагов изложенных ранее в работах С.А. Федотова и др. [2006, 2010, 2011] и в целом соответствует предполагаемой в работе [Koulakov et al., 2013] концепции динамичного изменения насыщения расплава в магматической питающей системе рассматриваемых вулканов. Доля магмы, аккумулирующейся под вулканами в процессе их функционирования, оценивается от $0.8 \%$ (Ключевской вулкан) до 72.9\% (вулкан Шивелуч) от магмы, извергающейся на поверхности Земли. Неожиданным и важным для оценки геотермальных ресурсов оказался вывод о возможности формирования высокотемпературных гидротермальных резервуаров под активными вулканами за счет глубинной циркуляции (до глубин от -10 до -35 км абс.), без необходимости дополнительных тепловых источников магматического происхождения. Тем не менее, наличие дополнительных магматических тепловых источников может повысить геотермальный потенциал.

\section{6. ЗАКЛЮЧЕНИЕ}

Анализ распределения плоско-ориентированных кластеров землетрясений под Ключевской группой вулканов и вулканом Шивелуч показывает следующее.

1) Первичный магматический очаг, питающий группу вулканов, находится, вероятно, на глубине $-165 . . .-205$ км под Ключевским вулканом, выше находятся зоны инжекции магмы в виде даек и силлов, интерпретируемые как коровый К2 (от 
-31 до -28 км) и периферический К1 (от -1 до +2 км абс.) магматические очаги.

2) Вулкан Толбачик характеризуется инжекциями даек в интервале глубин от -8 до -1 км.

3) Под вулканом Безымянный инжекции магмы происходят в виде силлов в диапазоне глубин от -2 до +2 км, где можно предполагать периферический магматический очаг. Его питание осуществляется по дайкам из корового магматического очага вулкана Ключевской К2.

4) Инжекции магмы в виде силлов в диапазоне глубин от -4 до -2 км абс. и от 0 до +2 км преобладают под вулканом Шивелуч, где можно предполагать наличие двух периферических магматических очагов.

Вулканы Ключевской группы являются индикаторами геомеханического состояния под ними.

5) Под Ключевским вулканом преобладают в целом условия горизонтального радиального растяжения (NF), в зонах корового К2 и периферического очага К1 фиксируются условия радиального сжатия (RF).

6) Под вулканом Толбачик преобладают условия горизонтального растяжения с ориентацией максимального горизонтального напряжения $\mathrm{S}_{\mathrm{Hmax}}$ в запад-север-западном направлении.

7) Под вулканами Шивелуч и Безымянный фиксируются условия горизонтального сжатия.

Зоны магматического фракинга (гидроразрыв при инжекции магмы в виде силлов и даек) в пределах активных вулканических аппаратов приводят к формированию проницаемых резервуаров с вертикальной протяженностью до 35 км (Ключевской) и поперечником до 15 км (Шивелуч) в зависимости от геомеханического состояния вмещающих массивов горных пород. iTOUGH2EOS1sc моделирование на примере Ключевского вулкана показывает, что в этих резервуарах происходит гидротермальная циркуляция с расходом от 12 до 106 кг/с (от 20 до 140 МВт) и формированием близповерхностных высокотемпературных $\left(220-300^{\circ} \mathrm{C}\right)$ геотермальных месторождений (кровля на отметках от 0 до -1.5 км абс.) за счет извлечения тепловой энергии из зон магматического фракинга и вмещающих их массивов горных пород. Авторы рассматривают создание профильных $\mathrm{X}-\mathrm{Z}$ термогидродинамических моделей с модулем состояния EOS1sc по профилям, изображенным на рис. 1, как первый этап решения задачи об условиях формирования гидротермальных систем, прилегающих к активным вулканам. На следующем этапе планируется преобразование XZ-моделей в XYZ-модели, исследования устойчивости решения от выбора вычислительной сетки.

Длительная гидротермальная циркуляция может создать возможности для формирования так- же рудных и нефте-газовых месторождений в результате геомеханического и термического воздействия магмы на вмещающие вулканогенноосадочные породы, и взаимодействия воды с горными породами, содержащими органическое вещество различного происхождения.

Авторы выражают признательность Е. Sonnethal (LBNL) за предоставление коллаборационной лицензии на использование программы iTOUGH2 v.7.1, S. Finsterle (Finsterle Geoconsulting) за консультации по использованию iTOUGH2 v.7.1. Авторы благодарны И.Ф. Делеменю, С.П. Позднякову и В.Г. Румынину за конструктивные замечания, использованные при доработке статьи.

Работа выполнена при поддержке РНФ по проекту № 16-17-10008.

\section{СПИСОК ЛИТЕРАТУРЫ}

Кирсанова Т.П., Юрова Л.М. Некоторые результаты гидрохимического изучения Толбачинского дола и перспективы поисков термальных вод // Вулканология и сейсмология. 1979. № 2. С. 85-95.

Кирюхин А.В., Сугробов В.М. Модели теплопереноса в гидротермальных системах Камчатки. М.: Наука, 1987. $149 \mathrm{c}$.

Кирюхин А.В., Делемень И.Ф., Гусев Д.Н. Высокотемпературные гидротермальные резервуары. М.: Наука, 1991. $160 \mathrm{c}$.

Кирюхин А.В. Моделирование эксплуатации геотермальных месторождений. Владивосток: Дальнаука, 2002. $216 \mathrm{c}$.

Кирюхин А.В., Кирюхин В.А., Манухин Ю.Ф. Гидрогеология вулканогенов. СПб.: Наука, 2010. 395 с.

Кирюхин А.В., Федотов С.А., Кирюхин П.А. Геомеханическая интерпретация локальной сейсмичности, связанной с извержениями и активизацией вулканов Толбачик, Корякский и Авачинский, Камчатка, 20082012 гг. // Вулканология и сейсмология. 2016. № 5. C. $1-18$.

Кирюхин А.В., Федотов С.А., Кирюхин П.А., Черных Е.В. Магматические питающие системы Корякско-Авачинской группы вулканов по данным локальной сейсмичности и режима прилегающих термальных источников // Вулканология и сейсмология. 2017. № 5. С. 3-17.

Макеев А.М., Кролевеи А.Н. Компьютерная программа поиска плоскостей пространственного группирования гипоцентров камчатских землетрясений // Вестник КРАУНЦ. Физ.-мат. науки. 2011. Вып. 2. № 3. С. 69-79.

Поляк Б.Г., Мелекесиев И.В. О продуктивности вулканов // Вулканология и сейсмология. 1981. № 5. С. 22-37. Федотов С.A. Магматические питающие системы и механизм извержений вулканов. М.: Наука, 2006. 456 с. Федотов С.А., Жаринов Н.А. Об извержениях, деформациях, сейсмичности Ключевского вулкана (Камчатка) в 1986-2005 гг. и механизме его деятельности // Вулканология и сейсмология. 2007. № 2. С. 1-29.

Федотов С.А., Жаринов Н.А., Гонтовая Л.И. Магматическая питающая система Ключевской группы вулка- 
нов (Камчатка) по данным об ее извержениях, землетрясениях и глубинном строении // Вулканология и сейсмология. 2010. № 1. С. 3-35.

Федотов С.А., Уткин И.С., Уткина Л.И. Периферический магматический очаг базальтового состава вулкана Плоский Толбачик, Камчатка: деятельность, положение и глубина, размеры и их изменения по данным о расходе магм // Вулканология и сейсмология. 2011. № 6. C. 3-20.

Федотов С.А., Славина Л.Б., Сенюков С.Л., Кучай М.С. Сейсмические процессы и перемещение магм, происходившие при Большом трещинном Толбачинском извержении 1975-1976 гг. и Трещинном Толбачинском извержении 2012-2013 гг. (п-ов Камчатка) // Геофизические процессы и биосфера. 2014. Т. 11. № 1. C. 3-30.

Kiryukhin A.V., Asaulova N.P., Finsterle S. Inverse modeling and forecasing for the exploitation of the Pauzhetsky geothermal field, Kamchatka, Russia // Geothermics. 2008. V. 37. P. 540-562.

Kiryukhin A. Analysis of Magma Injection Beneath an Active Volcano Using a Hydromechanical Numerical Model
(CFRAC) // EAGE conference "Horizontal wells", Kazan. 2017. 4 p. doi 10.3997/2214-4609.201700475

Kiryukhin A., Lavrushin V., Kiryukhin P., Voronin P. Geofluid Systems of Koryaksky-Avachinsky Volcanoes (Kamchatka, Russia) // Geofluids. 2017. Article ID 4279652. 2017. 21 p. doi $10.1155 / 2017 / 4279652$

Koulakov I., Gordeev E.I., Dobretsov N.L. et al. Rapid changes in magma storage beneath the Klyuchevskoy group of volcanoes inferred from time-dependent seismic tomography // J. of Volcanology and Geothermal Research. 2013. V. 263. P. 75-91. doi 10.1016/j.jvolgeores.2012.10.014

Magnúsdóttir L., Finsterle S. iTOUGH2-EOS1sc: Multiphase Reservoir Simulator for Water under Sub- and Supercritical Conditions User's Guide // LBNL-7017E. 2015. 17 p.

Pruess K., Oldenburg C., Moridis G. TOUGH2 User's Guide, Version 2.0. Rep. LBNL-43134, Lawrence Berkeley Natl. Lab., Berkeley, California, 1999. 198 p.

Shapiro S.A. Microseismicity a tool for reservoir characterization // EAGE Publications. 2008. 67 p.

Zoback M.D. Reservoir Geomechanics. Cambridge: University Press, 2010. 448 p. 